\title{
A comparative study between normal and chronic kidney patients during Hemodialysis
}

\section{Mehri Mirhaj Muhammadsalih}

Koya Technical Institute/Erbil Polytechnique University

Koya/ Erbil / Iraq

Mehrimirhaj78@gmail.com

\section{Rezhna Adil Rashid}

Rezhna_adil@epu.edu.krd

\section{Rowkhosh Ishaq Mekha}

Rowkhoshm@gmail.com

\section{Abstract}

The present study, included 71 patients ( 41 males and 30 females), suffering from chronic renal failure, who were attending Kidney Dialysis Center of Hawler Teaching Hospital in Erbil government, and 50 healthy individuals included as a control group. The sera were separated from patients and controls blood samples subjected to hematological studies. The aim of this study was to estimate changes in various hematological parameters in chronic renal failure patients before and after hemodialysis.

The study results showed that most of the hematological parameters were changed by hemodialysis in chronic kidney disease. Erythrocytes, hemoglobin, hematocrite were found to increase post-HD. The mean corpuscular volume, mean corpuscular hemoglobin and mean corpuscular hemoglobin concentration showed mild increase after hemodialysis. Leukocyte and platelet counts also showed mild increase after hemodialysis. It can be concluded that complete hematological parameters were found to increase after hemodialysis. Therefore, it is recommended that patients on hemodialysis should be investigated before and after hemodialysis to control the risk of anemia, bleeding or thrombosis .

Keywords: renal failure, hemodialysis, hematological parameters. 


\section{Introduction}

Chronic kidney disease (CKD) is one of the major public health problems, It is a continuous decreased loss of renal function which leads to long term renal treatment including renal replacement therapy (Khasawnah and Abeeleh, 2015). CKD is a progressive loss in renal function over a period of months or years, and it may lead to one of its recognized complications such as cardiovascular disease, anemia or pericarditis (Herzog et al., 2011).

Chronic renal failure is associated with a continuous reduction in glomerular filtration rate (GFr) which, in turn, causes the accumulation of various chemicals in the blood including urea and creatinine (Amin et al., 2014). It has been observed that chronic kidney disease is associated with anemia since erythropoietin production is reduced as a consequence of impaired function of kidneys in case of chronic renal failure (Hodges et al., 2007).

One of the renal therapeutic options is renal haemodialysis, which acts in removing body's waste products, including creatinine, urea and excess water (Amin et al., 2014). Hemodialysis is a method that is used to achieve the extracorporeal removal of waste products such as creatinine and urea and free water from the blood by an artificial kidney machine when the kidneys are in a state of renal failure. The basic principle of the artificial kidney is to pass blood through minute blood channels bounded by a thin membrane. On the other side of the membrane is a dialyzing fluid into which unwanted substances in the blood pass by diffusion (Guyton and Hall, 2011). The frequency of haemodialysis is 2-3 times per week, whereas dialysis time ranged from 2-4 hours depending on several factors among which are kidney function, amount of waste in body, level of salts and body weight. Several complications have been associated with haemodialysis such as sleeping sickness, exhaustion low blood pressure, chest pain, nausea, leg cramp, anemia and headache (Unruh et al., 2011).

Studies have identified increased blood pressure to be one of the main factors causing kidney failure. It is plausible that hypertension induces kidney failure through impacting the blood vessels within the kidney which, in turn, has effects on the secretion of waste products. It has been observed that the waste may be secreted into extra cellular fluid leading to more increased blood pressure ending with esrd (Santulli and laccarino, 2013).

\section{Materials and Methods}


This research was conducted on 71 patients (41males and 30 females) with chronic kidney disease who attended the Kidney Dialysis Center of Hawler Teaching Hospital in Erbil government.

Venous blood samples were collected in dipotassium (EDTA) containers, labelled and tested for platelet count while, for Hemoglobin estimation (Sahli method, Micro-Hematocrit method, described by Dacie \& Lewis, was adopted to measure the packed cell volume (PCV) using micro hematocrit centrifuge (10000 g for 5 minutes), and the standard capillary tubes. Total and differential leukocyte count (WBC) was performed by manual methods. For counting the WBC, blood samples were diluted 1 in 20 using $2 \%$ glacial acetic acid solution as a diluent, which lyses the red cells and stains white cells. They were counted microscopically using improved neubauer chamber. Differential leukocyte count was performed manually using thin blood films. Blood films were prepared, stained with leishman's stain and examined under the microscope to evaluate the morphological features of blood cells. Red blood cell count was used to assess the numerical variation of patients' blood and performed by manual $1 \%$ formal citrate method using improved neubauer chamber and, red cell indices ( $\mathrm{MCV}, \mathrm{MCH} \& \mathrm{MCHC}$ ) were calculated. For counting platelets, blood samples were diluted 1 in 20 using $1 \%$ ammonium oxalate solution as a diluent, which lyses the red cells. Platelets were counted manually using improved neubauer chamber, Blood samples from 50 control subjects were obtained for comparison.

Statistical analysis was performed by SPSS (Statistical package for social science) version 17.0. Using descriptive statistic, LSD (Least Significant differences) test for multiple comparisons after ANOVA, $p$ value $\leq 0.05$ was considered as significant.

\section{Results}

The results showed the differences between the mean of RBCs, Hb, Hct, MCV, MCH and $\mathrm{MCHC}$ indices that occurred in renal failure patients before and after HD compared to the control group (Table 1). A statistically significant $(p<0.05)$ decrease in RBCs count was observed in pre- HD patients (3.4283 \pm 0.684$)$ as compared to the post-Hd (3.5045 \pm $0.689)$ with the control group $(5.2378 \pm 1.715)$. The $\mathrm{Hb}$ concentration also showed a statistically significant decrease in pre-HD patients $(8.8141 \pm 1.802)$ as compared to the post-HD $(8.8521 \pm 1.766)$ to the control group $(15.2353 \pm 5.530)(P<0.05)$. The Hct level similarly showed a statistically significant decrease $(P<0.05)$ in pre-HD patients $(28.6620$ 
$\pm 5.717)$ compared to the post-HD $(29.1873 \pm 5.712)$ and to the control group $(44.1510 \pm$ 9.74). The MCV also showed a statistically significant change (80.6157 \pm 11.690$)$ compared to the post-HD (83.7901 \pm 6.812$)$ and the control (83.9592 \pm 6.415$)$, similar to the indices mentioned above, $\mathrm{MCH}$ level showed a statistically significant decrease in pre-HD patients $(25.3859 \pm 2.841)$ when compared to that of the post-HD $(25.8239 \pm 2.864)$ and control group $(28.1510 \pm 1.535)(\mathrm{P}<0.05)$. However, the $\mathrm{MCHC}$ showed a statistically significant change $(30.3662 \pm 2.276)$ if compared to the post-HD $(30.8155 \pm 2.205)$ and control group (32.5157 \pm 5.346$)$, All the measured indices showed a statistically significant increase in post- HD patients $(P<0.05)$.

Table(1): The differences between mean of RBC indices before and after hemodialysis procedures in patients and healthy controls.

\begin{tabular}{|l|l|l|l|l|}
\hline Lab. Findings & $\begin{array}{l}\text { Before } \\
\text { Hemodia. }\end{array}$ & After Hemodia. & Control & P value \\
\hline RBC & $3.428 \pm 0.684$ & $3.504 \pm 0.689$ & $5.237 \pm 1.715$ & 0.000 \\
\hline Hemoglobin & $8.814 \pm 1.802$ & $8.852 \pm 1.766$ & $14.235 \pm 5.530$ & 0.000 \\
\hline Hematocrite & $28.662 \pm 5.717$ & $29.187 \pm 5.712$ & $44.151 \pm 9.74$ & 0.000 \\
\hline Hct & $80.615 \pm 11.69$ & $83.790 \pm 6.812$ & $83.959 \pm 6.415$ & 0.056 \\
\hline & & & & 0.000 \\
\hline MCH & $25.385 \pm 2.841$ & $25.823 \pm 2.864$ & $28.151 \pm 1.535$ & \\
\hline & & & & 0.02 \\
\hline
\end{tabular}

\section{Values are expressed as mean \pm SD.}

Table (2), showed the differences between mean of leucocytes and differential count before and after hemodialysis compared to the control group, the renal failure patients before HD did not exhibit any significant differences between the mean number of leucocytes and differential count, the result of the present study showed that there were statistically insignificant differences between mean number of leucocytes and differential count in renal failure patients pre-HD procedures and post-HD. The WBC counts showed significant 
increase in post-HD patients $(7.6338 \pm 2.362)$ compared to the pre-HD patients $(7.5451 \pm$ $2.395)$ to the control group $(8.0646 \pm 5.011)$ at $(P<0.05)$; the neutrophil counts showed a statistically significant increase in post-HD patients $(5.6451 \pm 2.004)$ compared to that of the pre-HD $(5.6437 \pm 2.038)$ to the control group $(4.4557 \pm 1.370)$ at $(P<0.05)$. However, the lymphocyte showed a statistically significant increase in post-HD patients $(1.3155 \pm$ $0.428)$ compared to pre-HD $(1.2873 \pm 0.456)$ to the control group $(4.7137 \pm 12.350)$ at $(P>0.05)$. The lymphocyte\% count showed statistically significant increase in post-HD $(18.2451 \pm 6.868)$ when compared to the pre- HD $(17.8887 \pm 6.766)$ and that of the control group $(31.1392 \pm 10.071)$ at $(P<0.05)$, the neutrophil\% counts showed significant increase post-HD (74.7225 \pm 7.409$)$ when compared to that of the pre-HD (73.3718 \pm 7.331$)$ and that of the control group $(59.3373 \pm 14.160)$ at $(P<0.05)$. Finally platelet $(P L T)$ counts were significantly higher in post-hemodialysis patients $(176.7183 \pm 55.777)$ than in prehemodialysis (175.3239 \pm 55.656$)$ and that of control $(210.2353 \pm 57.157)$.

Table (2): Differences between mean of leucocytes and differential count before and after hemodialysis:

\begin{tabular}{|l|l|c|c|c|}
\hline Lab. Findings & $\begin{array}{l}\text { Before } \\
\text { Hemodia. }\end{array}$ & After Hemodia. & Control & P value \\
\hline WBCs & $7.545 \pm 2.395$ & $7.633 \pm 2.362$ & $8.064 \pm 5.011$ & 0.667 \\
\hline
\end{tabular}




\begin{tabular}{|l|c|c|c|c|}
\hline Neutrophiles & $5.643 \pm 2.038$ & $5.645 \pm 2.004$ & $4.455 \pm 1.370$ & 0.001 \\
\hline Lymphocytes & $1.287 \pm 0.456$ & $1.315 \pm 0.428$ & $4.713 \pm 12.350$ & 0.005 \\
\hline Lymphocytes & $17.888 \pm 6.766$ & $18.245 \pm 6.868$ & $1.139 \pm 10.071$ & 0.000 \\
\hline Neutrophiles & $73.371 \pm .331$ & $74.722 \pm 7.409$ & $9.337 \pm 14.160$ & 0.000 \\
\hline Platelets & $175.323 \pm 55.65$ & $176.718 \pm 55.77$ & $210.235 \pm 57.15$ & 0.001 \\
\hline
\end{tabular}

\section{Values are expressed as mean \pm SD.}

\section{Discussion}

The results of the present study showed that patients with chronic kidney diseases on regular hemodialysis display variations in hematological parameters. The RBCs count, hemoglobin and hematocrit levels in chronic kidney disease patients were significantly lower when compared to the levels in healthy controls. The present study showed that the mean of each RBCs count, $\mathrm{Hb}, \mathrm{Hct}, \mathrm{MCV}, \mathrm{MCH}$, and $\mathrm{MCHC}$ levels show a significant increase in chronic kidney patients' post-HD when compared to pre-HD levels, these results similar to that of (Alghythan and Alsaeed, 2013), which explained that increase of each RBCs count, $\mathrm{Hb}$, Hct levels post-HD were explained by the fact that before HD, patients are usually hypervolemic.

Red blood cell count, hemoglobin and hematocrit values were significantly lower in hemodialysis patients compared to controls, this is similar to the results of the (Yassin et al., 2014), which indicated that RBC, hemoglobin, and hematocrit were significantly lower in hemodialysis patients than in controls. This indicates that hemodialysis patients are more likely to be Anemic these may be due to impaired function of the kidneys which results in reduction of erythropoietin, as (Hodges et al., 2007), in their study demonstrated that chronic kidney disease is associated with anemia since erythropoietin production is reduced as a consequence of impaired function of kidneys in case of chronic renal failure.

Erythropoietin is a glycoprotein hormone produced by the kidneys and its responsible for the activation of bone marrow to secrete erythrocytes so decrease in erythropoietin causes anemia, due to the inability of the failing kidneys to secrete erythropoietin (EPO), and other factors which suppress marrow erythropoiesis and shortened red cell survival (Suresh et al., 2012; Portolés, et al., 2013) indicated that among the common complications in persons with end stage renal disease, are anemia mainly due to loss of erythropoietin production, or the cause of anemia may be one of these factors that (Anees et al., 2010; 
Olasunkanmi et al., 2012) pointed that anemia in hemodialysis patients may be due to many factors including blood loss, shortened red cell life span, vitamin deficiencies, the "uremic milieu," renal erythropoietin deficiency due to kidney failure, iron deficiency, and inflammation. $\mathrm{MCV}, \mathrm{MCH}, \mathrm{MCHC}$ showed a significant increase in post hemodialysis patients the same results were obtained by the (Ali et al., 2008)

The result of this study showed that the mean of WBCs, neutrophiles, lymphocytes, count were significantly increased in renal failure patients post-HD when compared to that of the control group, and the cause of this increase may be infection or inflammation as (Afshar et al., 2010; Hsu et al., 2010) previously mentioned that the hemodialysis patients suffer inflammation which is associated with increased number of WBCs, It was also observed that the mean of leucocytes counts and the mean count of each, neutrophils, lymphocytes, showed statistically significant increase in chronic kidney patients' after hemodialysis when compared to before hemodialysis procedures. The increase of leukocytes and differential counts after- hemodialysis may be explained by the fact that at the beginning of hemodialysis, patients are usually hypervolemic.

Platelets also showed a statistically significant increase in post hemodialysis compared with pre hemodialysis, same results were reported by the (Yassin et al., 2014), which explained that White blood cell (WBC) and platelet (PLT) counts were significantly higher in hemodialysis patients than in controls, also the same results were obtained by the (Lokesh et al., 2014). Platelet count, was found to be lower in cases when compared to healthy controls (Ali et al., 2008), concluded that data concerning platelet count before and after dialysis, suggest that there may be other factors affecting platelets during dialysis.

It can be concluded that complete hematological parameters were found to increase after hemodialysis. Therefore, it is recommended that patients on hemodialysis should be investigated before and after hemodialysis to control the risk of anemia, bleeding or thrombosis .

\section{References}

- Afshar, R., Sanavi, S., Salimi, J. and Ahmadzadeh, M., 2010. Hematological profile of chronic kidney disease (CKD) patients in Iran, in pre-dialysis stages and after initiation of hemodialysis. Saudi Journal of Kidney Diseases and Transplantation, 21(2), p.368. 
- Alghythan, A.K. and Alsaeed, A.H., 2013. Hematological changes before and after hemodialysis. Scientific Research and Essays, 7(4), pp.490-497.

- Ali, M.S.M., Babiker, M.A., Merghani, L.B., Ali, F.A.A.T. and Abdulmajeed, M.H., 2008. Hematological changes post-hemo and peritoneal dialysis among renal failure patients in Sudan. Saudi Journal of Kidney Diseases and Transplantation, 19(2), p.274

- Amin, N., Mahmood, R.T., Asad, M.J., Zafar, M. and Raja, A.M., 2014. Evaluating urea and creatinine levels in chronic renal failure pre and post dialysis: a prospective study. Journal of cardiovascular disease, 2(2), pp.1-4.

- Anees, M., Mumtaz, A., Ibrahim, M., Shaheen, S.M. and Asghar, A., 2010. Effect of Anemia and Hyperhomocysteinemia on mortality of patients on Hemodialysis. Iranian journal of kidney diseases, 4(1), p.60.

- Guyton and Hall, 2011. Textbook of medical physiology. Saunders.

- Herzog C, Asinger R, Berger A, Charytan D, Di'ez J, Hart R, Eckardt K, Kasiske B, McCullough P, Passman R, DeLoach S, Pun P, Ritz, E, et al, 2011. Cardiovascular disease in chronic kidney disease. A clinical update from Kidney Disease: Improving Global Outcomes (KDIGO). Kidney ISN 2011.10.1038/ki .223.

- Hodges V M, Rainey S, Lappin T R and Maxwell A P (2007). Pathophysiology of anemia and erythrocytosis. Critical Reviews in Oncology/Hematology, 64: 139-158. -Hsu, C.W., Lin, J.L., Lin-Tan, D.T., Yen, T.H. and Chen, K.H., 2010. White blood cell count predicts all-cause, cardiovascular disease-cause and infection-cause oneyear mortality of maintenance hemodialysis patients. Therapeutic Apheresis and Dialysis, 14(6), pp.552-559.

-Khasawnah, N. and Abeeleh, J.A.A.A., 2015. Hematological and biochemical findings among jordanian patient with end stage renal disease. European Scientific Journal, ESJ, 11(3).

- Lokesh, S., Green, S.R., Mathew, T.K., Hemachandar, R., Kumar, A., Tiwari, S.R., Lakshmi, A. and Ezhumalai, G., 2016. A comparative study of platelet parameters in end stage renal disease patients undergoing haemodialysis and healthy individuals. International Journal of Advances in Medicine, 3(3), pp.559-563.

- Olasunkanmi, S.A., Olasunkanmi, S.A., Adindu, C., Sikiru, B., Mohammed, M., Mohammed, S., Mohammed, A.R. and Mohammed, a.a., 2012. Haematological profile of patients with chronic kidney disease in nigeria. Journal of Nephrology and Renal Transplantation, 5(1), pp.2-10. 
- Portolés, J., Gorriz, J.L., Rubio, E., De Álvaro, F., García, F., Alvarez-Chivas, V., Aranda, P. and Martinez-Castelao, A., 2013. The development of anemia is associated to poor prognosis in NKF/KDOQI stage 3 chronic kidney disease. BMC nephrology, 14(1), p.2.

- Santulli G, Trimarco B and laccarino G (2013). G-protein-coupled receptor kinase 2 and hypertension: molecular insights and pathophysiological mechanisms.. High Blood Pressure Cardiovascular Prevention, 20(1): 5-12.

- Suresh M, Mallikarjuna reddy N, Sharan B Singh M, Hari Krishna Bandi, Shravya keerthi G, Chandrasekhar M , 2012. Hematological Changes in Chronic Renal Failure International Journal of Scientific and Research 2(9)

- Unruh A, Kurella M, Brett T, Larive C, Rastogi A and James S (2011). Impact of Sleep Quality on Cardiovascular Outcomes in Hemodialysis Patients: Results from the Frequent Hemodialysis Network Study. American Journal of Nephrology, 33: 398-406.

- Yassin, M.M., Lubbad, A.M.H., AbuTaha, A.J. and Saadallah, N.M., 2014. Homocysteine and hematological indices in hemodialysis patients. Ibnosina Journal of Medicine and Biomedical Sciences, 6(4), pp.173-179.

\section{نبذة مختصرة}

في الدر اسة الحالية ، تم الحصول على البيانات من 71 مريضا (41 من الذكور و 30 من الإناث) الذين كانوا يعانون من الفشل الكلوي المزمن و كانو ا يحضرون مركز غسيل الكلى في مستشفى هولير التعليمي في محافظة أربيل بالعر اق ، و تم مقارنتهم مع 50 من الأفر اد الأصحاء كمجموعة سيطرة. تم فصل الأمصال من عينات دم المرضى الخاضعين للار اسات الدموية. كان الهدف من هذه الدر اسة هو تقدير التغير ات في معايير الدم المختلفة التي تحدث في مرضى الفثل الكلوي المزمن قبل وبعد غسيل الكلى.وأظهرت نتائج قياس الدراسة أن معظم المعلمات الدموية قبل وبعد غسيل الكلى في مرضى الكلى المزمن إما زيادة أو نقصان. علاوة على ذلك ، لوحظ أن معظم القيم الدموية ارتفعت بعد عملية غسيل الكلى. و ايضأ ، تم العثور على خلايا الدم الحمراء ، و الهيمو غلوبين ، و حجم الخلايا المضغوطة زيادة ما بعد عملية غسيل الكلى. و أظهر MCHC ، MCH ، MCV زيادة معتدلة بعد عملية غسيل الكلى. كما أظهرت عدد الكريات البيض و الصفائح الدموية زيادة معتدلة بعد غسيل الكلى. بمكن الاستتناج بأنه قياس كل المعلمات الدموية أظهرت زيادة بعد عملية غيل الكلى.ولذلك ، فمن 
المستحسن أن يتم فحص المرضى الذين يعانون من غسيل الكلى قبل وبعد غسيل الكلى للتحكم في خطر فقر الدم ، و النزيف أو تجلط الدم.

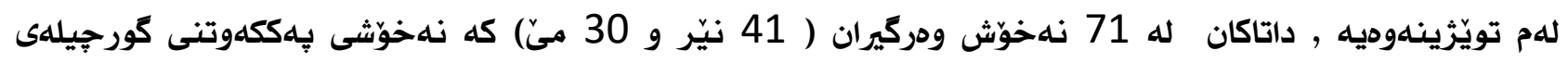
دريّزخايهنيان هلبوو و سلردانى سلنتهرى شووشتنهوهى كَورجيلهيان دمكرد له نهخوّشخانهى هلوليّرى فيّركارى له

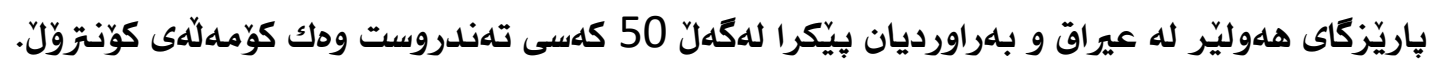

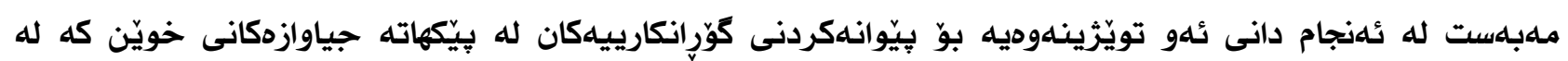
نهخوُشانى بِككهوتنى كَورجيلهى دريّزخايلهن دا هليه بلهر له كردارى شوشتنهوه و له دواى كردارى شووشتنهوهى كَورجيله و نُهنجامهكان ئهوديان به ديار خست كه كه بِيّوانهى زوّربهى بِيّكهاتهكانى خويّنى نهخوّشهكان يان زياد يان

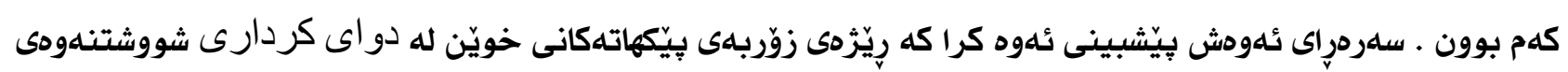




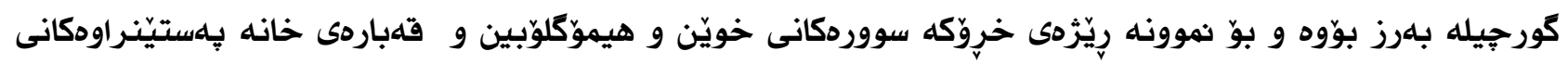
خويّن MCHC ، MCH ، MCV و hematocrite كهميّك بهرزبوونهوهيان به خوّوه بينى له دواى كردارى شووشتنهوهى كَورجيله , وه ئهوهمان دهست كهوت كه رِيّزَهى بِيّكهاتهكانى خويِن له دواى كردارى شووشتنهوهى كَورجيله

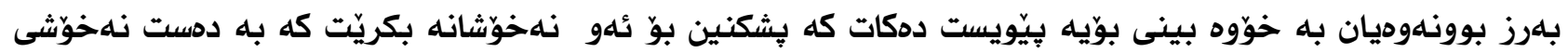

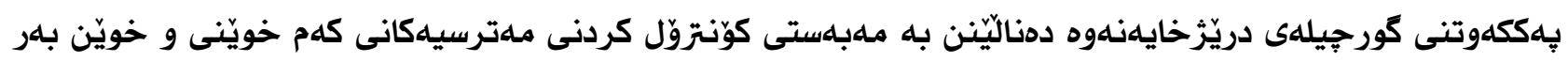
بوون و ملهيينى خويَن. 